\title{
ISTANBUL 2: a hieroglyphic fragment from Tabal in the Haluk Perk Collection
}

\author{
İknur Taş and Mark Weeden \\ Hitit Universitesi, Çorum and School of Oriental and African Studies, University of London
}

\begin{abstract}
The article publishes an unprovenanced fragment of a stele housed in the Haluk Perk Museum in Istanbul. Palaeography and manner of inscription suggest an origin in the eighth century BC in the region known to the Neo-Assyrians as Tabal. The new text is largely incomprehensible due to its fragmentary state, as well as the fact that it contains otherwise unattested words and signs. However, in one case, a rare combination of signs persuades us to revise the reading of part of another recently published hieroglyphic document from the same period and area. The Istanbul text appears to contain a historical narrative relating to a warlike encounter. The article presents the text in hand-copy, photo, transliteration and translation, as well as supplying a detailed philological commentary.
\end{abstract}

\section{Özet}

Söz konusu makale, İstanbul'daki Haluk Perk müzesinde bulunan orijini belirsiz bir stel parçası ile ilgilidir. Yazıtın tarzı ve paleografik özellikleri söz konusu parçanın Yeni Asur çağında Tabal olarak bilinen bölgede M.Ö.8.yüzyılda kaleme alınmış olabileceğini düşündürmektedir. Metnin büyük bir kısmı kırık yapısından dolayı anlaşılmaz durumda olup, ayrıca tanımlanamayan işaret ve sözcükler içerdiği görülmüştür. Bununla birlikte söz konusu bölgede aynı çağ içinde kaleme alınmış yakın bir tarihte yayınlanan bir başka hiyeroglif belge de söz konusudur. Stelimizdeki bazı işaret formlarının oluşturduğu az sayıdaki kombinasyon bizi bu metnin bir bölümünü yeniden gözden geçirmeye itmiştir. İstanbul metni bir savaşla ilişkili tarihsel bir hikâyeyi içermektedir. Metnin elde yapılmış bir kopyası ile resim, tercüme ve transkripsiyonunun yer aldığı söz konusu çalışma çerçevesinde ayrıca metne ilişkin filolojik nitelikli bir detaylı yorum da kaleme alınmıştır.

$\mathrm{T}$ his fragment of a stele is currently in the private museum collection in Istanbul belonging to Mr Haluk Perk, who has kindly allowed us to bring it to the attention of the scholarly community. Its museum inventory number is Haluk Perk Museum no. M2909. Its philological value lies in containing one previously unattested word, of uncertain meaning, one new sign and in contributing to the ongoing clarification of two otherwise poorly attested logographic writings. It may mention a warlike encounter, possibly a massacre, and could be from a royal inscription. It is referred to as ISTANBUL 2.

Find-circumstances and location are unknown, but style and execution suggest it is probably to be classed among the inscriptions of the area known to the NeoAssyrians as Tabal and to be dated to the eighth century BC. It thus most likely comes from south-central Anatolia, specifically Cappadocia, additionally including the area directly to the north of the Kizılirmak river. For this definition of Tabal, see Weeden 2010. Closest similarities exist with the Assur Letters (Hawkins 2000: 533-55, pls 306-13), Kululu inscriptions (Hawkins 2000: 442-503, pls 244-88), inscriptions from the wider Niğde area (Hawkins 2000: 513-31, pls 290-305) and the recently published Kırşehir Letter (Akdoğan, Hawkins 2007-2008; 2011; Giusfredi 2010: 236-39).

The stele is incised on three sides with sign-forms resembling what has been termed by J.D. Hawkins the 'Kululu-style' (Hawkins 2000: 430), although all elements typical of that style to be found here can also be attested in inscriptions from the Niğde area. Attention is drawn to the forms of the signs $w a / i$ and CAPUT. The sign $s a$ is written in the later form, as is $n a$. The sign for 100 appears to be written once in a cursive and once in monumental style. There is one case of (graphic?) 
aphaeresis, a sure indicator of a late time of inscription, at least after the middle of the ninth century BC (Melchert 2010: 149-50). On the other hand, the preserved fragment does not show the use of final -' to indicate the end of a word, a phenomenon usually restricted to inscriptions of the eighth century BC. Absence of this orthography does not exclude an eighth century date, however.

The shape of the preserved part of the monument is a rectangular block. The smaller side (B) measures $22 \mathrm{~cm}$ across, the larger side (C) is $42 \mathrm{~cm}$ high by $37 \mathrm{~cm}$ across as preserved (figs 1,2). The inscribed areas are set at right angles to each other and appear to share a line-divider, thus indicating that the text may have run continously from side $\mathrm{A}$ to $\mathrm{B}$ to $\mathrm{C}$ and back from $\mathrm{C}$ to $\mathrm{B}$ to $\mathrm{A}$. However, it is entirely unclear if there was a divide between any of these sides, which would mean that none of them presented text connected with the others. This cannot be established with certainty from the preserved text, as there are no clear cases where text runs on from either side to side or line to line. It may be that one or each of the sides runs directly from line 1 to line 2, rather than across the corners to the next side. It is not clear which side would have faced the front or whether a fourth side would have existed, and further not clear on which side the inscription may have begun. The labelling of the sides as $\mathrm{A}, \mathrm{B}$ and $\mathrm{C}$ is thus based only on the orientation of the preserved script, the ordering of the lines being hypothetical and provisional. In the most extreme case, these could be three different inscriptions, although some thematic coherence does appear.

Remains of three lines are preserved on side A, dextroverse-sinistroverse-dextroverse, also on side $\mathrm{C}$, dextroverse-sinistroverse-dextroverse, the middle line being the best preserved in each case. Clearly, at least a fourth line would have existed above the top line of $\mathrm{C}$, as indicated by the remains of a line-divider at the highest point of this side. Side B, the most damaged, contains remains of two lines, dextroverse-sinistroverse.

The arrangement of the signs is not entirely regular, with word-dividers apparently being used twice in C $\left(2^{\prime}\right)$ to indicate syntactic divisions in the middle of a column of signs. The position of the DEUS-sign at the bottom of a column in $\mathrm{C}\left(1^{\prime}\right)$ is also highly irregular, as it is in A ( $\left.3^{\prime}\right)$ if the reading is correct. Similar irregularity in the positioning of signs is to be found in the GEMEREK stele from the southwest of the Sivas region (Akdoğan, Hawkins forthcoming).

Side A:

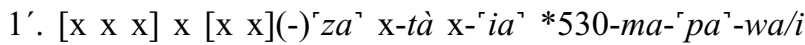

| ARHA x-ma-ni-ta

Side B:

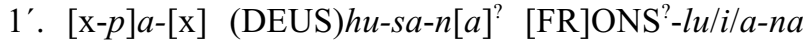
'x'-pa-ri+i [x x]-l[u/i/a]'-[x]

Side C:

1'. [x]-[p]a-[w]a/i? "CAPERE"(-)sa-ru-sa|COR-ni x(-) $t u-w a / i-s i[\mathrm{x} \times]-m u-p a-[\mathrm{x} \times \mathrm{x}]$ DEUS [x x x-s]a

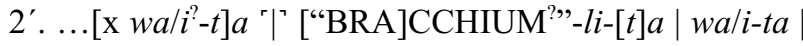

M II C CAPUT- $t i-n a$ ARHA "CAPUT.CULTER.LINGUA $+\mathrm{x}$ "- $i$-ta $\mid a-w a / i$ DOMUS-ni-i DOMUS- $n i \mid \mathrm{C}$ x [...]

Side B:

$2^{\prime}$. [...]ku $[\mathrm{x} \mathrm{x}]{ }_{\llcorner} a^{?}$,

Side A:

2'. [x]-sa | "'[] LIGNUM" $h a+r a / i, z a-t i ! w a / i-m a-t a$ CI CUM-ni ARHA "PES 2 "-wa/i-si-tà wa/i+ra/i "CAE[LUM"?]-pa-si-i [...]

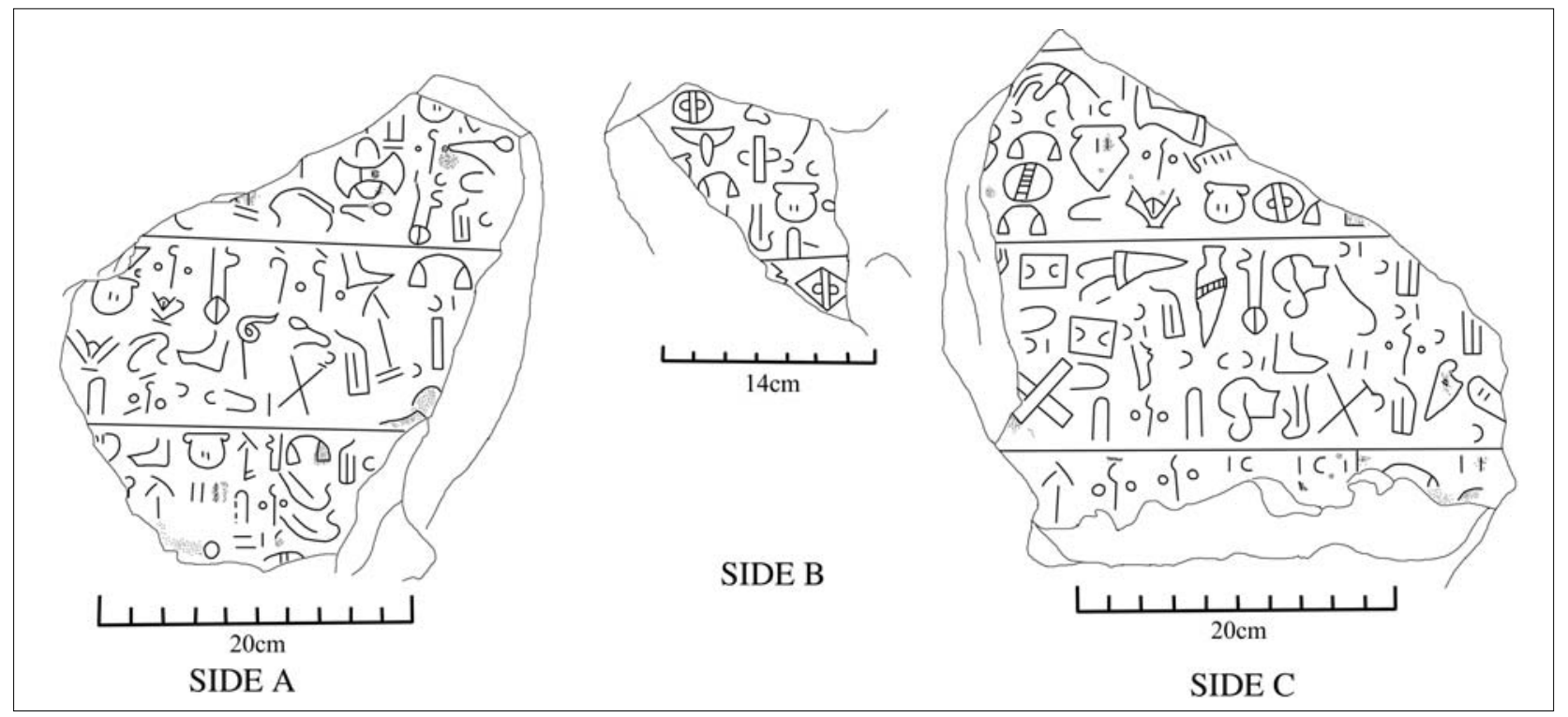

Fig. 1. Drawing of ISTANBUL 2, traced from photographs in Photoshop CS4 and collated on stone 
Side A:

$3^{\prime}$. [...] $\mathrm{x}_{-} u^{?},-[\mathrm{x}]-t i-z i^{?}$ pa $\mathrm{II}^{?}[\mathrm{x}] \quad z a-i a(-)[\mathrm{x}] a-w a / i$ (DE[US])sa-na-na(-)ta [...]

Side C:

$3^{\prime}$. [...] zi/a $[\mathrm{x} \mathrm{x}] w a / i-[\mathrm{x} \mathrm{x}] w a / i-[\mathrm{x} \mathrm{x}]|[\mathrm{x} \mathrm{x} \mathrm{x}]| \mathrm{x}[\mathrm{x} \mathrm{x}]$

$l^{?}\left[\begin{array}{lll}\mathrm{x} & \mathrm{x} & \mathrm{x}\end{array}\right] \mathrm{x}[\mathrm{x} x] \mid \mathrm{x}[\mathrm{x} x]$

A: (1') [he x]-ed the [x]-es, but (they?) completely damaged the $\mathrm{x}$-es

B: $\left(1^{\prime}\right) \mathrm{x}$ the god Husa? the foremost he $[\mathrm{x}]-\mathrm{es} .$.

$\mathrm{C}$ : ( $\left.1^{\prime}\right)$ plunder he/I x-ed for him/myself personally. But me the god...

C: $\left(2^{\prime}\right)$ [and] they over [came] him there, and 1,200 men they slaughtered. And to each house $100 \ldots$

B: $\left(2^{\prime}\right) \ldots$

A: (2') he possesses and he took away 101 of them from me with (him) and [...] them to the heaven...

A: $\left(3^{\prime}\right) \ldots$ and the god Sanana(nta)?

C: $\left(3^{\prime}\right) \ldots$

A (1'): x-tà most likely third singular preterite verb, possibly with object in sentence final position. The following clitic chain would then be attached to a noun (neuter plural accusative) expressed by the previously unattested sign in *530-ma, which may or may not partially resemble a double-axe. The sign is given a new number. It was decided not to include it among the double-axe sign-forms under $* 281$ because of its vertical as opposed to horizontal orientation and the obscurity of the elements above and below the 'axe-blade'.

The closest verb to x-ma-ni-ta would be imanita, a verb indicating a negative action towards an inscription attested only in the inscriptions of Commagene (reference courtesy J.D. Hawkins), but the traces exclude ${ }^{\top} i-m a-n i$ ta. That verb is written $a$-tá (OCCIDENS) $i$-ma-ni-ti BOYBEYPINARI 1-2, IIA §7, IIIB 2 §11 (Hawkins 2000: 338); a-tá (OCCIDENS)[i-ma-ni-t]i ADIYAMAN $1 \S 4$ (Hawkins 2000: 345); a-tá i-ma-ni-ti ANCOZ $7 \S 11$ (Hawkins 2000: 357). In ISTANBUL 2 the action of the verb is qualified by the adverb $A R H A$, rather than $a$-tá. The traces also exclude reading [OCCID]ENS-ma- $n i-t a$.

B (1'): (DEUS)hu-sa-x unidentified divine name. Broken sign to left may be $[p] a$, perhaps belonging to a clitic chain. Possibly Huwassana, the Bronze Age deity of Hupisna, could be compared (van Gessel 1998: 169-73, $632-34)$. If the final sign $\left(-n[a]^{?}\right)$ belongs to the stem of this name, it could be dative 'foremost to Husana'. Otherwise, and more likely, it is an unknown (DEUS)Husa, in the accusative and qualified as hantilin. [FR]ONS?-lu/i/a-na (reading suggested by J.D. Hawkins) would display the usual spelling of hantili- 'foremost' seen in KARATEPE Ho $\$ 26$ (Hawkins 2000: 61), ' $\mathrm{x}$ '-pa-ri+i could be an ablative noun with rhotacism or a verbal form in the third singular present.
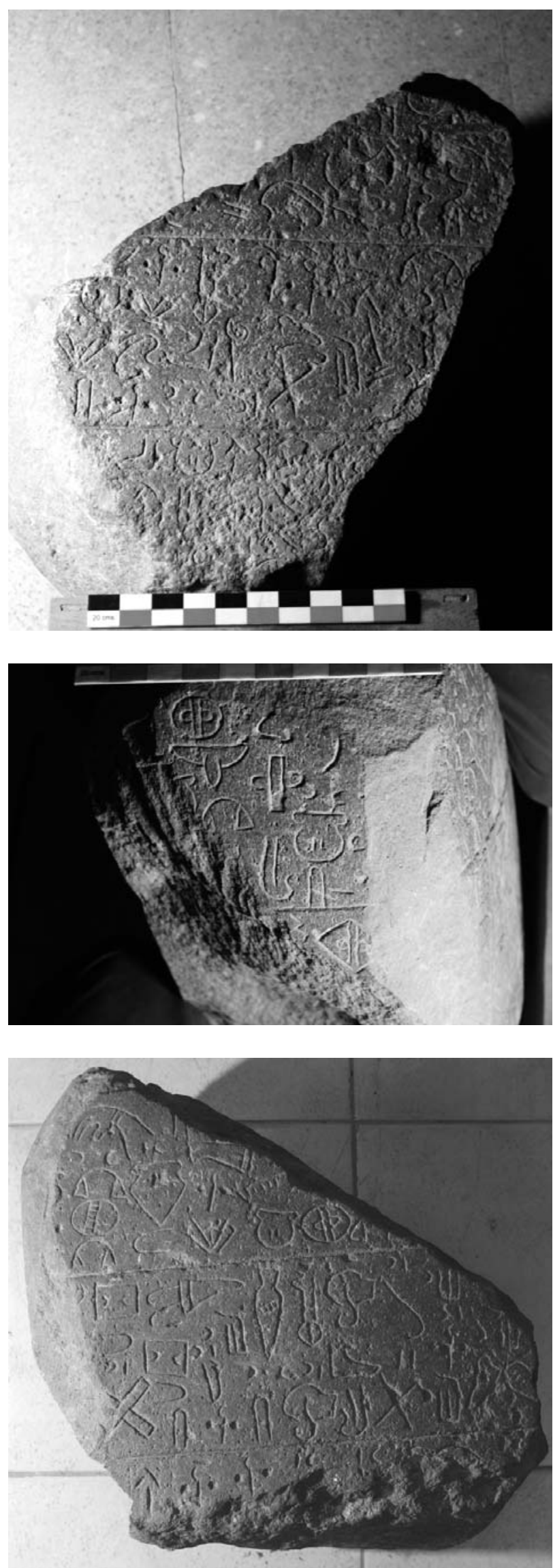

Fig. 2. Photographs of Istanbul 2: top side A; middle side B; bottom side C (photos I. Taş) 
C (1'): “CAPERE”(-)sa-ru-sa neuter singular probably nominative $u$-stem like matu- 'wine', or $t$-stem like tarut- 'statue'. If this is a full phonetic writing after a logogram, it may be connected to Hittite saru- 'plunder' (Chicago Hittite Dictionary Š 296). This might suit the ideogram CAPERE, which is used as a logogram for the verb 'take', Luwian la- (Yakubovich 2008: 20-24), and as a determinative for the difficult verb or verbs written $u$-pa-, which clearly can mean 'to bring' (Hawkins 2000: 260), but additionally have a meaning that has been interpreted as either 'establish' (Yakubovich 2005: 243-45) or 'dedicate, furnish' (Melchert 2004: 374). The meaning of our lexeme (x-)sa-ru-sa must remain unclear, however, and an etymological argument is the weakest basis for suggesting an interpretation.

The most immediate interpretation of the verb-form would identify it as a second singular present tense (-)tuwasi, but this is very unlikely in a narrative inscription. Otherwise it would have to end in the reflexive/mediopassive -si (on which, see last Yakubovich 2010: 201-02). It would need to have "CAPERE"(-)sa-ru-sa as subject or object. The morpheme /-si/ can, but does not have to, effectively delete a previous verbal ending ( $i$-zi-ia-si ÇİNEKÖY $\S$ VI, §VII; Tekoğlu, Lemaire 2000: 968). It is thus unclear whether $t u-w a / i$-si is first or third person. COR$n i$ stands for atni (dative-locative singular), 'form, figure, self', closely related to atri-. A potentially similar double marking of the reflexive, this time using the enclitic reflexive particle - $m i$ beside COR-tara/ $i$-sa instead of the post-verbal element $-s i$, is to be found in KIRŞEHİR $§ 10$ (Akdoğan, Hawkins 2007-2008: 9; Giusfredi 2010: 236). A mediopassive reading of the verb would give us 'the (x-)saru is put in the atni'. It is always possible that atni has a more concrete meaning here, perhaps 'image' (Hawkins 2000: 447, 460). The verbal ending -asi may mark the end of the sentence, but this would leave too much space for the beginning of the next sentence, presumably $[a ́-] m u-p a-[w a / i]$.

$\mathrm{C}\left(2^{\prime}\right)$ : the second $-t a$, followed by the word-divider, presumably marks a verbal ending belonging to the word designated by the broken logogram in the bottom right. Quite possibly third plural preterite due to not being written with -tà, but see next clause. The logogram is probably an arm of some kind, and could be [BRACCH]IUM or [FOR]TIS, with -li-ta as phonetic complements. wa/i-ta shows aphaeresis for $a=w a=t a$ with the Ortspartikel -ta. According to Melchert (2010) this would be purely graphic.

CAPUT- $t i-n a$ is singular, as usual with numbers. CAPUT- $t i$ - is translated by either Phoenician ' $d m$, 'man' (KARATEPE §XXXXIV, §LXI) or $r z n$, 'prince' (KARATEPE §LX; Hawkins 2000: 66). It is possibly a word for 'man, person' (Giusfredi 2010: 135) that is semantically related to a word for 'head', but not Luwian harmahi-, as the phonetic complement shows.

"CAPUT.CULTER.LINGUA+x"- $i$-ta verb-form in third singular or plural preterite. Plural number is perhaps more likely due to the use of $-t a$ instead of $-t a ̀$ (Rieken 2008). The logogram is interesting and may refer to some kind of mutilation of corpses, execution by decapitation or other warlike activity. There are two related contexts that are relevant but also very obscure.

The bipartite logographic compound CAPUT.CULTER occurs as the verb ARHA CAPUT. CULTER-tá in an unclear immediate context at KARKAMIŠ A24a2+3, 2 $\S 3$ (Hawkins 2000: 133-39), where it is either third singular or plural preterite, with donkeys/horses, or people associated with donkeys/horses, as either subject or object. There it also stands in an unclear relationship to a town called Parnasa or possibly a man from Parna. J.D. Hawkins (2000: 136) interprets the second part of the logogram as a knife (CULTER), a reading which is supported by the present attestation: KARKAMIŠ A24a2+3, $\quad \S 3: \quad p a+r a / i$-na-sa-pa-wa/i-ta-'(URBS)

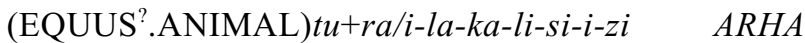
CAPUT.CULTER-tá (see Hawkins 2000: 135-36) '(they x-ed away/off the TURLAKALI-people) (from) the city Parnasa (double accusative)/in the city Parnasa (dativelocative)/from the man of Parna city (dative of genitive adjective)'.

The TURLAKALI-people could also be the subject if the verb is intransitive. A larger context in KARKAMIŠ A $24 \mathrm{a} 2+3$ is hostile activity on the part of the Assyrian king, which is mentioned in the next line. Hawkins (2000: 136) reads the determinative on TURLAKALI as (ASINUS 2 .ANIMAL). The characteristic lump under the chin of ASINUS $_{2}$ is missing, however. The ears being swept forward might suggest rather the logogram EQUUS, 'horse', this being one typical differentiation from the sign ASINUS 'donkey', while ASINUS $_{2}$ has both the ears swept forward and usually a lump under the chin. See the form of EQUUS at ANDAVAL §4: (EQUUS)á-sù-wa/i-za (Hawkins 2000: 515, pl. 291). However, Fragment 11 of KARKAMIŠ A24 has the EQUUS sign in the monumental form, which is quite different (Hawkins 2000: 137). Furthermore, the classification of these various signs and their ideographic values is extremely difficult from text to text (Hawkins, Morpurgo-Davies 1998; Hawkins 2005: 295-96). TURLAKALI-people attached to horses might be more likely to be mentioned as victims or aggressors of military action against a city than people associated with donkeys, but the closer context remains unclear. The main point is that this is a warlike encounter. 
In ISTANBUL $2 \mathrm{C}\left(2^{\prime}\right)$ we appear to have a tripartite compound logogram, with the logogram markers placed under the central sign: CULTER. The third sign, $\mathrm{LINGUA}+\mathrm{x}$, is new. It clearly consists of the 'tongue'sign (LINGUA), with two hooked appendages. However, in a damaged and obscure part of the Kırşehir Letter a similar sign may occur, also in combination with CAPUT and most likely also with CULTER. As the sign was unknown at the time, the editors originally reinterpreted it as la (LINGUA), with the phonetic value, assigning the two dashes on its right (script running left to right) to the nearby sign $i$, thus giving -ia. An early draught of R. Akdoğan's drawing of the lead strip from Kırşehir/Yassıhöyük did include the two hooked ends of these dashes, but these were later interpreted by the editors as part of the damage. This original but incomplete drawing is reproduced here with the kind permission of R. Akdoğan and J.D. Hawkins (fig. 3). J.D. Hawkins further points out after photo collation that the sign below LINGUA+x in the Kırşehir Letter resembles more the sign CULTER, as suggested by ISTANBUL 2, than it does a damaged $-i$, as he had originally read it. The text of the relevant passage of the Kirşehir Letter may thus run: KIRŞEHIR §11: $\mathrm{CRUS}_{2}-n u \dot{u}-p a-w a / i-{ }^{\top} t a^{\top}$ tá-ti$n a \mid h a+r a / i-{ }^{2} z a^{\text {? }}-i-{ }^{\prime}$ *366'-na-na INFRA? CAPUT.

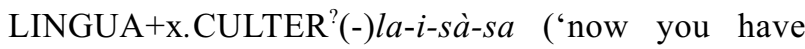
repeatedly x-ed (him) down? the father...').

The passage is hardly clear. The verb may be an iterative in $-s a$ - (second singular preterite), of which ISTANBUL 2 would attest the simplex stem $(-i-)$, most probably in the third person plural preterite, $\mathrm{x}(-)$ layinta (vel sim.).

DOMUS- $n i-i$ DOMUS-ni: repetition of word interpreted as distributive in function.

Side A ( $\left.2^{\prime}\right)$ offers the only possible but thin evidence of continuity from side to side along a line, if only in that both it and $\mathrm{C}\left(2^{\prime}\right)$ contain numerals. The reading ([“]LIGNUM”) $h a+r a / i, z a-t i$ (third singular present), suggested to us by J.D. Hawkins, gives an unusual order of the signs, as does wa/i-ma-ta $(w a=m u=a n=t a)$. An alternative reading of this chain as $w a=m u=a d a$, 'and to me they/it (went away)', would run counter to the usual writing of this enclitic pronoun with -tà (Rieken 2008) but would better fit the otherwise attested intransitivity of the verb $\operatorname{PES}_{2}(-)$ wasi- (see below).

The first verb, ("LIGNUM $\left.{ }^{["]}\right)_{2} h a+r a / i,-z a-t i$, is perhaps the same verb as (*69)harza (second singular imperative), which is known from the ASSUR Letters in the phrase interpreted as 'get hold of them (and) send them off to me': wa/i-ra+a|("*69")ha+ra/i-za|wa/i-ma$r a+a\left|A R H A^{-i}\right|$ VIA-wa/i-ni, ASSUR b §6-7 (Hawkins 2000: 534, 545). The significance of "LIGNUM" instead of $* 69$ as determinative is obscure. It is usually used as a

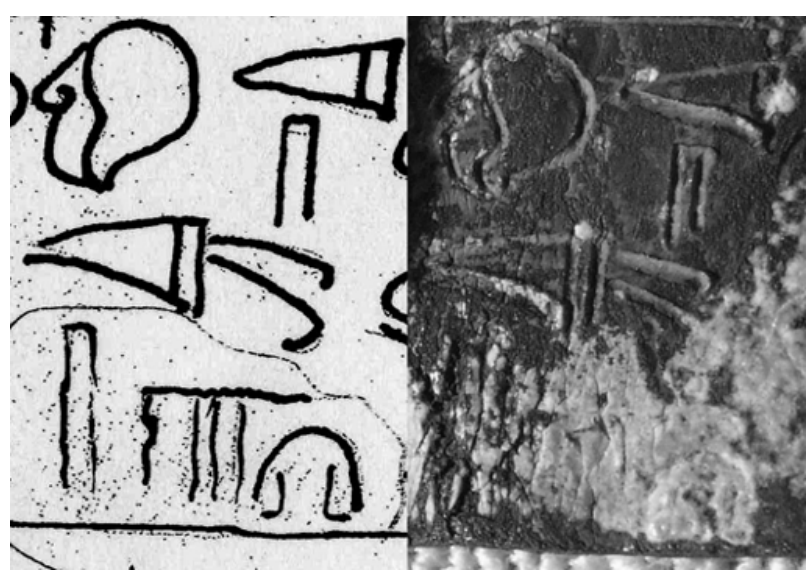

Fig. 3. Detail from preliminary drawing of KIRŞEHIR Letter $\$ 11$ (drawing and photo R. Akdoğan; courtesy of the Museum of Anatolian Civilisations, Ankara)

determinative to words for items made of wood, and by extension for words connected with authority: (LIGNUM)hazani-, (LIGNUM)salhatt-. Possibly violent taking possession is meant. The object of the verb is lost in the break, but presumably resumed by the enclitic pronoun $=\mathrm{an}=$ in $w a=m u=a n=t a$ (written $w a / i-m a-t a)$. The numeral 101 is then in apposition to this. The sequence of tenses, present-preterite, is also problematic. wasi(ya) - with the determinative $\mathrm{PES}_{2}$ : CUM-ni PES $_{2}(-) w a / i-s i$-ti TELL AHMAR $5 \S 17$ (Hawkins 2000: 234) where it apparently means 'come (against)'. See also, VERSUS-ia-na PES $_{2}-s i$-ti at KARKAMIŠ A31+ $\S 10$ (Hawkins 2000: 143). In these two cases, parallels with $\mathrm{PES}_{2}-w a / i$ - suggest an intransitive verb of motion. Here a transitive use is suggested by the orthography of the enclitic chain.

A (3'): sense entirely obscure, not helped by a further otherwise unattested divine name. Possibly related to Bronze Age Hittite DSanta, who is sometimes equated with Marduk (van Gessel 1998: 372-73, 607-08), although this is a very remote guess. The possibility of an alternative reading is suggested by J.D. Hawkins, who compares $\mathrm{SA}_{4}-n a-n a-l a-s a$ at BOYBEYPINARI 1-2 §11 (Hawkins 2000: 336, 338). This word may have a full phonetic writing at IVRIZ Fragment 2 ' $\mathrm{SA}_{4}$ '(-)REL-na$n a$-[la?]-sá (Hawkins 2000: 530; Giusfredi 2010: 152 53), which would make the comparison with (DE[US] ')sa-na-na(-) less likely. The sign after $p a$ could conceivably be $m i$.

\section{Acknowledgements}

We are most grateful to Mr Haluk Perk of Istanbul for his permission to publish this piece and for his hospitality during İlknur Taş' visits to work on it. Further thanks are due to Professor J.D. Hawkins for discussing the stele 
with us and to Dr R. Akdoğan for graciously providing access to her work. Professor Daniel Schwemer also supplied useful comments on an earlier draught of the article. The Oliver Gurney Memorial Fund of the British Institute at Ankara met some of the costs incurred by İlknur Taş during her work on this project. Mark Weeden's research is funded by a Post-Doctoral Fellowship from the British Academy.

\section{Bibliography}

Akdoğan, R., Hawkins, J.D. 2007-2008: 'KırşehirYassıhöyük'ten ele geçen luvi hiyeroglif yazılı kurşun levha' Anadolu Mediniyetleri Müzesi'nin Yılliğl 2007-2008: 7-14

- 2010: 'The Kırşehir Letter: a new Hieroglyphic Luwian text on a lead strip' in A. Süel (ed.), VII. Uluslararası Hititoloji Kongresi Bildirileri, Çorum 25-31 Ağustos 2008/Acts of the VIIth International Congress of Hittitology, Çorum, August 25-31, 2008. Ankara: 1-16

— forthcoming: 'A stele from Gemerek' $T \ddot{U} B A-A R$

Giusfredi, F. 2010: Sources for a Socio-Economic History of the Neo-Hittite States (Texte der Hethiter 28). Heidelberg

Hawkins, J.D. 2000: Corpus of Hieroglyphic Luwian Inscriptions I.1-3. Berlin

- 2005: 'VIII.3. Commentaries on the readings' in S. Herbordt, Die Prinzen- und Beamtensiegel der hethitischen Grossreichszeit auf Tonbullen aus dem Nişantepe-Archiv in Hattuša (Boğazköy-Hattuša 19). Mainz: 248-313

Hawkins, J.D., Morpurgo-Davies, A. 1998: 'Of donkeys, mules and Tarkondemos' in J. Jasanoff, H.C. Melchert, L. Oliver (eds), Mír Curad - Studies in Honor of Calvert Watkins. Innsbruck: 243-60
Melchert, H.C. 2004: 'A Luwian dedication' in J.H.W. Penney (ed.), Indo-European Perspectives. Studies in Honour of A. Morpurgo-Davies. Oxford: 370-09 - 2010: 'Spelling of initial /a-/ in Hieroglyphic Luwian' in I. Singer (ed.), ipamati kistamati pari tumatimis. Luwian and Hittite Studies Presented to J. David Hawkins on the Occasion of his 70th Birthday. Tel Aviv: 147-58

Rieken, E. 2008: 'Die Zeichen $<$ ta $>$, $<$ tá $>$ and $<$ tà $>$ in den hieroglyphen-luwischen Inschriften der Nachgroßreichszeit' in A. Archi, R. Francia (eds), VI Congresso Internazionale di Ittitologia Roma, 5-9 settembre 2005 (= Studi Micenei ed Egeo-Anatolici 50): 637-48

Tekoğlu, R., Lemaire, A. 2000: 'La bilingue royale Louvito-Phénicienne de Çineköy' Comptes-rendus des Séances de l'Académie des Inscriptions et Belles-Lettres 2000: 961-1007

van Gessel, B.J.H. 1998: Onomasticon of the Hittite Pantheon I. Handbuch der Orientalistik I/33. Leiden

Yakubovich, I.S. 2005: 'Carian monument' in N.N. Kazanskii (ed.), Hrda Manasa: Studies Presented to Leonard G. Herzenberg on the Occasion of his 70th Birthday. St Petersburg: 240-51

- 2008: 'Hittite-Luvian bilingualism and the origin of Anatolian hieroglyphs' Acta Linguistica Petropolitana 4: 9-36

- 2010: Sociolinguistics of the Luvian Language (Brill's Studies in Indo-European Languages and Linguistics 2). Leiden

Weeden, M. 2010: 'Tuwati and Wasusarma. Imitating the behaviour of Assyria' Iraq 72 (In Honour of the Seventieth Birthday of Professor David Hawkins): 39-62 